\title{
Improving the technical knowledge and background level in engineering training by the education digitalization process
}

\author{
Konstantin Kryukov, Svetlana Manzhilevskaya*, Konstantin Tsapko, and Irina Belikova \\ Don State University, 344000, Rostov-on-Don, Russia
}

\begin{abstract}
The modern technical education digitalization implies an increase in the role of the information component in the training of students. At the same time there is a certain gap between the modern technologies training and the understanding of the fact that construction industry is the mixture of historically formed features and the current state of the industry. Nowadays construction industry is under continuous technical development. The main danger of an insufficient attention to the special aspects of the construction development is the neglect of the preservation of cultural background and architectural heritage, which can be observed in the modern life.

The article deals with the issues of improving the effectiveness of the educational process of students by introducing into the educational training process not only modern methods of designing building structures, but also the issues of understanding the history of the emergence of individual construction objects. The construction object can't appear out of nothing.

All constructive solution is preceded by a historical situation the situation of cultural and architectural heritage. However, there is no discernible connection between technical education and the humanities and social sciences.

The authors use historical examples to justify the need for the use of elements of the humanities by a teacher of a higher technical educational institution with the introduction of the capabilities of modern digital information modeling technologies.
\end{abstract}

\section{Introduction}

The modern technical education digitalization implies an increase in the role of the information component in the training of students. At the same time there is a certain gap between the modern technologies training and the understanding of the fact that construction industry is the mixture of historically formed features and the current state of the industry. Nowadays construction industry is under continuous technical development. The main danger of an insufficient attention to the special aspects of the construction development is the neglect of the preservation of cultural background and architectural heritage, which can be observed in the modern life. Such activities as the destruction of

\footnotetext{
*Corresponding author: lncs@springer.com
} 
historic urban centers, the replacement of historical monuments with new-builds, the 3D modeling without the comprehensive historical and technological analysis of the design solutions can lead to the lack of the most valuable cultural and historical objects, including entire urban agglomeration.

There for it is very important to do the groundwork for situation where technical education digitalization shouldn't replace or cancel the getting the knowledge of the story behind of modern building structures.

Modern building construction textbooks contain the brief overview of the origin story behind the building structures sometimes, but these overviews are focused on a generalized, rough description of most known samples of architecture and do not mention the structures that appeared in the Industrial revolution time and made a base for a modern construction.

Although technical education is based on science and its applications, at the same time there are the raising concerns about the lack of the solid relationship between technical education and humanities and social sciences, especially nowadays due to the shut out the courses about the history of architecture and art from the Industrial and civil engineering training course. As usual all these courses become the elective ones, but it is only a partial solution to the problem. In this way the authors suggest the complex way of elements of the humanities practical application into the construction engineering training connected with the reviewing the achievements of technological solutions, using the powerful capabilities of modern Building Information Modeling (BIM) technologies for building construction and remodelment.

\section{Materials and methods}

The certain building structure application expresses a particular idea because of the specific intention of the designer or because of the unconditional demand of the project owner. For the past 100 years artists, poets, critics and historians observed and reflected these ideas in their works, which represent a kind of a contribution to the theory of structures, as works of Claude Navier [1], A. E. H. Love [2] and Stephen Timoshenko [3].

Steelwork structures not only inspired engineers to create new construction equipment, but also became a symbol of the time for architects, artists and writers. Modern life of the world was changing, influenced by the gearing up pace of industrial and economic development. The process of migration made population go away from agricultural areas to cities and towns. The artists had the opportunity to create their work on another way and moreover inspired people to think on another way. The Eiffel Tower representation by Robert Delaunay made in 1910 and shown in figure 1, contributed to the emergence of Orphism, the offshoot of abstract art, which dominated the first half of the twentieth century. Thus, if the Eiffel Tower in 1889 represented the highest achievement of a new construction technology, then in 1910 the same tower became a symbol of a new ideology in art, according to which Parisian outstanding structures, such as the domes of The National Residence of the Invalids, The Pantheon, The Basilica of the Sacred Heart, shown in figure 2, were considered senseless and archaic, and were considered inspiring the new way of living. It seemed that the tower opened up new ideas in art just as it stabled new methods in construction engineering. 


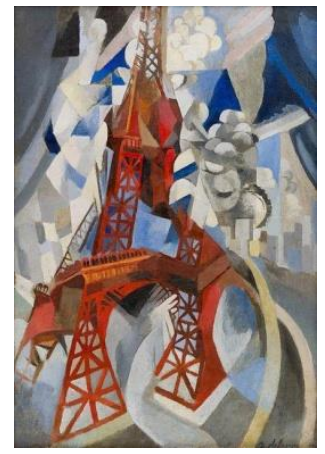

Fig. 1. "Red Eiffel Tower" by Robert Delaunay, 1911-1912
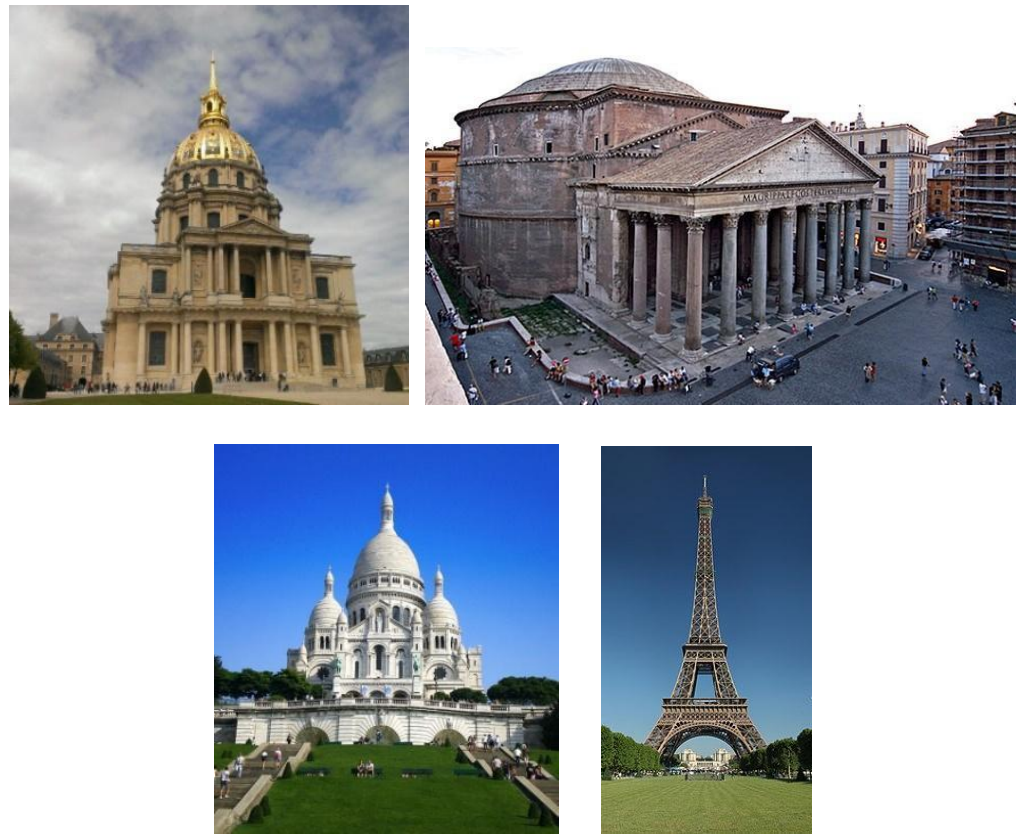

Fig. 2. The Parisian outstanding structures of the old and new ideologies: 1 . The National Residence of the Invalids, 2. The Pantheon, 3. The Basilica of the Sacred Heart, 4. The Eiffel Tower.

In France, this connection between construction engineering and art was nothing new. The outstanding examples of this connection have been found at the recent past in the nineteenth century. Here, about long before Delaunay, Victor Hugo declared the awakening of interest in ancient buildings, when he described in his novel "Notre-Dame de Paris" the poorly maintained and crumbling Cathedral of Notre-Dame de Paris, shown in figure 3 [4]. Hugo took this cathedral as a hero, and its restoration was the true purpose of writing the novel. He described man's disregard for his own creations. Hugo's call for the restoration of the cathedral found a response in the literary circles of post-Bourbon France, and finally it reached the young student of architecture, Eugène Emmanuel Viollet-le-Duc who became the founder of the architectural restoration of cultural heritage. Viollet-le-Duc wrote [5] that aesthetics were a direct result of influence of building structural system and showed how the form in Gothic architecture was related to the acting forces. Based on the results of this study, he concluded that the correct way of building engineering means to allow the shape of the building to follow logically from the building structural system. This explanation became for Viollet-le-Duc an absolute requirement for engineering. In the Gothic style, he 
stabled not to focus at architectural look, but rather suggest to the designer another way of thinking. His model of such thinking was a rational design, typical of engineers. In fact, his ideas might never have gained such popularity, if not for several civil engineers-path breakers, such as Gustave Eiffel and John Roebling, who, didn't share the existing theoretical views on the Gothic style, went forward and created outstanding structures that illustrated the rationality of the theory.

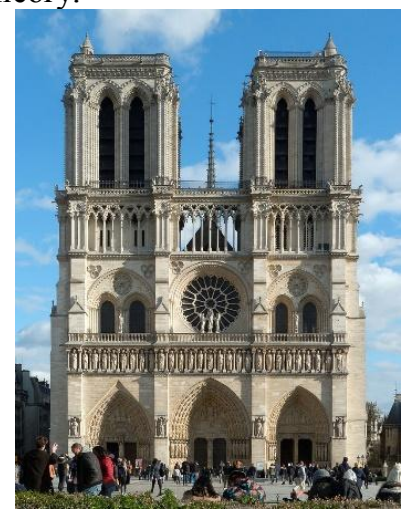

Fig. 3. Notre-Dame de Paris, 1163-1345, Paris

Even before the construction of the tower, Eiffel designed a series of huge doublehinged metal arches for railway bridges in central France. His largest designed arch, The Garabit Viaduct, shown in figure 4, visually reflects each of the main carrier functions of the structure: the parabolic curve approaches the stress block from evenly distributed vertical loads; the large cross-section of the arch in the center of the span decreases towards the hinges, reflecting the perception of the bending moment created by temporary and unevenly distributed permanent loads; the small width of the cross-section of the arch in the arch key increases towards the supports, reflecting the bending resistance under the influence of wind load.

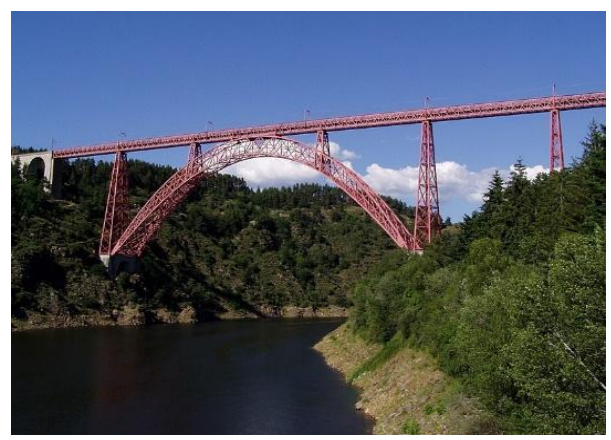

Fig. 4. The Garabit Viaduct, 1885, France

In all cases, the shape corresponds to the work of the structure, and this bridge is still a model for the study of arch structures, as it was after its construction was completed in 1885. The studying the works of Eiffel [6-8] not only provides an opportunity to improve the level of engineering training, but also directly leads to an understanding of the humanitarian impact of engineering on art and architecture, for example, the influence of this bridge of the nineteen century on the modern construction and modern culture.

The fact that this bridge had a great influence on architects can be seen in two important books that reflect the engineering ideas of the early twentieth century. The Garabit Viaduct is the first illustration in Le Corbusier's book «Toward an Architecture» (1927) [9], the 
most famous polemical work on the modernist trend in architecture, written by its most influential representative.

In America, the role of Eiffel was shared by two civil engineers: John Roebling and James Eads. Their works were considered in the spirit of Viollet-le-Duc as a monumental illustration of rational construction. These two men, like Eiffel, were both talented structural designers and business people who were extremely successful. They reached maturity as designers, like Eiffel, just as steel structures began to replace cast iron ones. Their large bridges were immediately recognized as the rational design of the structure by two people, famous architect Louis Sullivan and architecture critic Montgomery Schuyler, who played much the same role for the modern architecture of the late nineteenth century in America that Le Corbusier and Sigfried Giedion played for the modern trend in architecture one generation later.

The steel skyscraper first appeared in Chicago shortly after the great fire of 1871 as a response to the desire of the modern businessman to intensively use the land. From the group of Chicago architects who sought to introduce a new steel frame to architecture, two great men stood out: Frank Lloyd Wright and his teacher, Louis Sullivan, who studied in Paris during the golden age of Viollet-le-Duc's career, whose ideas were very close to him. In Sullivan's autobiography [10], he tells that in his youth, he was deeply impressed by the suspension bridge, and how James Eads later became his hero. He kept track of the construction of the Eads steel arches in 1872-1874, shown in figure 5. The arches were shaped in such a way that the bridge's own weight created negligible bending moments. Like the arches of Eiffel, these arches had nothing in common with the typical masonry arches, and Sullivan instinctively saw in them the expression of the very law that he repeated in this form: "Form depends on function." And this law he sought to follow, emphasizing the load-bearing frame in the skyscrapers he built in Chicago, St. Louis and Buffalo.

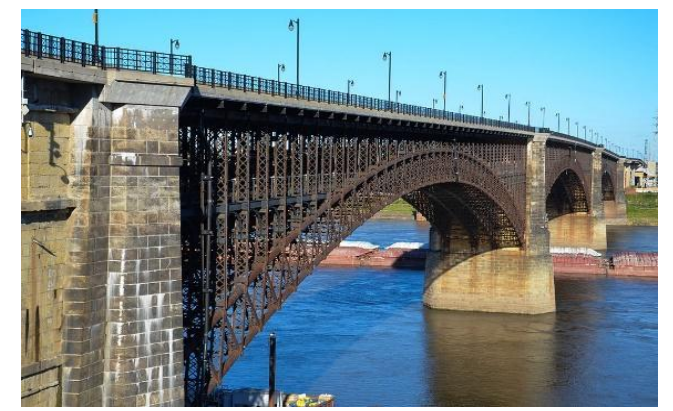

Fig. 5. Eads Bridge over the Mississippi River, 1874, USA

In 1867, when Eads began building his bridge [11], John Roebling signed a contract with the New York Bridge Company to design and build a bridge connecting the two cities of New York and Brooklyn. Roebling, who emigrated from Germany in 1831, came to the United States with a strong desire to build suspension bridges. The ultimate manifestation of this desire was his Brooklyn Bridge project, shown in figure 6. Although Roebling died from an injury sustained on the construction site in 1869, long before the bridge construction was completed, he finished the project. His confidence in the fact that this bridge will be outstanding is reflected in his report to the bridge-building firm, in which he wrote: "The projected bridge, if completed in accordance with my design, will not only be the most outstanding existing structure, but also the most remarkable engineering structure of our century on this continent. Its most characteristic feature is the high pylons; they will serve as lighthouses for the neighboring cities and will be worthy of being considered national monuments of architecture." [12]. 


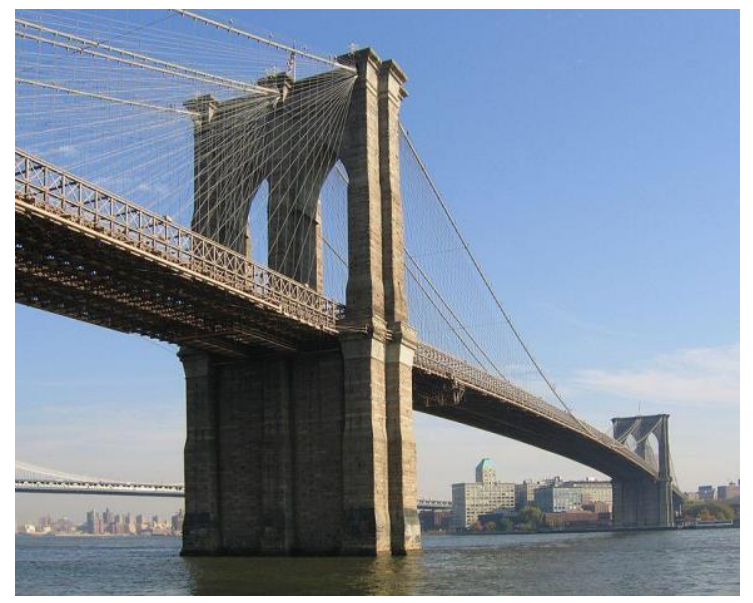

Fig. 6. The Brooklyn Bridge by John Roebling, 1883, USA

This bold statement was confirmed in every respect. In 1964, the Brooklyn Bridge was indeed officially declared a national monument by the US government. Technically, the bridge was the height of the building art of the time, in particular because of its deep caissons, submerged with compressed air and larger than any ever built; its thousands of steel ropes for a span of $458 \mathrm{~m}$ were $50 \%$ longer than in any of the previously built suspension bridges; and the famous stone pylons were much higher than any building or structure in New York. Moreover, in the moment when the bridge construction was completed in 1883, Montgomery Schuyler recognized the monumental nature of the bridge in his critical article [13], which was perhaps the first significant article by an architectural critic devoted entirely to a structure designed by an engineer. The fact that Schuyler can view the bridge as a work of art is mainly due to his fascination with the recently translated works of Viollet-le-Duc [5]. His article "The Brooklyn Bridge" (1883) is largely a retelling some of his architectural essays appeared as American Architecture: Studies (1892) [14]. For Schuyler, the Brooklyn Bridge embodies Viollet-le-Duc's ideas about construction and architecture, so that he can immediately recognize the works of Sullivan and Wright, along with those of Roebling, as truly pioneering and emblematic of the modern world.

\section{Results}

Schuyler paid so much attention to the Brooklyn Bridge for two mutually related reasons: first, to declare this structure the most outstanding and characteristic architectural monument of its time, and, secondly, to show how an engineering structure becomes a work of art, being rationally designed. He described the steel bracing wires and spandrel hangers as spider web architecture of this aerial arch and perfect as an organism created by nature. He told that the designer of the Brooklyn Bridge perfected the expression of function in a work where the lines of action of forces determined the shape of structures.

Since any building in the future will increasingly become the work of engineers, the rest of us, as well as engineers should strive to ensure that the shape of the building always reflects its purpose, especially in modern times, when the customer perceives each building as a kind of self-valuable object, unrelated to the surrounding architecture. There is only one way that can really lead to such a result: it is necessary to supplement the construction engineering training program with courses of architectural appearances of a building. 


\section{Discussion}

There is a lack of proper attention to aesthetic issues and architectural appearances of a building in the construction engineering training programme.

The Eads Bridge, as well as the Eiffel and Roebling Bridges, marked the birth of modern structures, as the shape of these structures, the materials used, and the calculation methods were the first to recognize the structural capabilities of steel. At the same time, Viollet-le-Duc was developing (based on the results of studying structures of a completely different type in restored cathedrals) the theory of modern structures.

The combination of the theory of the architectural history with the practice of the engineer is precisely the goal that, according to the authors, should be pursued by the teachers of modern construction training universities.

This combination means that the masterpieces of modern architecture should be used as examples for studying the calculation of structures and as illustrations of the implementation of ideas in art, architecture and literature. So, for example, the calculations of the arches, so carefully described by C. M Woodward's "History of the St. Louis Bridge" (1881) [15] is mostly such as a modern engineer can use. Thus, if such a book is recommended for reading in the appropriate course on structures, the student will be able to study the calculation of arches while studying the Eads Bridge, and at the same time learn something about the enormous cultural significance of the first engineer whose name is listed in the American Pantheon of Fame.

The Eads Bridge and the Brooklyn Bridge, like the Eiffel Tower inspired outstanding artists. One of them, Joseph Stella, devoted a significant part of his life to painting pictures of the Brooklyn Bridge, shown in figure 7. He was as fascinated with the Roebling Bridge as Robert Delaunay was with the Eiffel Tower. His paintings were different from mass postcards with sentimental paintings. They are a personal perception of the modern world, in some way similar to the perception of the world by several great engineers like John Roebling.

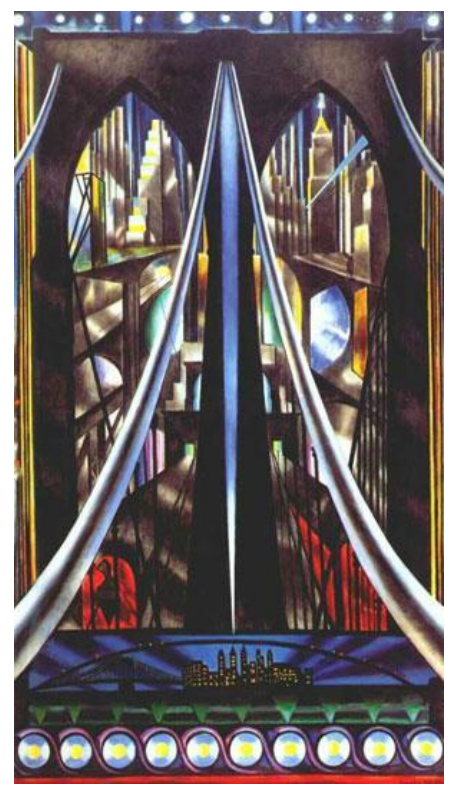

Fig. 7. The Brooklyn Bridge by Joseph Stella, 1939, USA 


\section{Conclusion}

Thus, summarizing all of the above, we can say that engineering education in the field of building structures should begin with a return to the study of the outstanding masterpieces of the recent past. Then, on these structures, students can learn methods for calculating designs that would result in being connected to the ideas they symbolized and inspired. Multidisciplinary and multi-faceted educational courses with the use of digital educational information technologies could serve as auxiliary reading material, illustrating the ability of structures to influence people and their culture. And finally, the lectures should address the ideas of appropriate design, the constant struggle between technical efficiency and visual finesse - ideas that were first popularized by Viollet-le-Duc almost a century ago, but although extremely necessary, are largely ignored at the present time.

The bringing a sense of system and beauty to the process of training engineers is the essential component for the seasoned professionals training, that's why the authors suggest a return to the elevating study of the achievements of people like Eiffel, Eads and Roebling.

\section{References}

1. A.B. Saint-Venant, C. Navier, Résumé des leçons donnée à l'École des ponts et chausses, Paris, 420 (2011).

2. E.A. Milne, Love Augustus Edward Hough, Obituary Notices of Fellows of the Royal Society of London III, 467-482 (1939-41).

3. S.P. Timoshenko, J.M. Gere, and W. Prager, J. Appl. Mech. March 29(1), 220-221 (1962).

4. Victor Hugo, 1802-1885 The Hunchback of Notre-Dame (London, New York, Dutton, Dent) 510 (1973).

5. Viollet-le-Duc, Eugène-Emmanuel, Entretiens Sur L'architecture 1 (French Edition, Nabu Press, 566, 2010).

6. Henri Loyrette, Gustave Eiffel (Rizzoli, New York, 586, 1985).

7. David I. Harvie, Eiffel, the Genius who Reinvented Himself: Stroud, Gloucestershire: Sutton, (2006).

8. Wolfgang M. Freitag, ed., Art Books: A Basic Bibliography of Monographs on Artists6 (New York, London, Garland Publishing) 124-125 (1997).

9. Le, Corbusier, and Frederick Etchells, Towards a New Architecture (New York, Dover Publications, Print, 312 (2014).

10. Kaufman, D. Mervyn, Father of Skyscrapers: A Biography of Louis Sullivan (Boston, Little, Brown and Company) (1969).

11. Louis How, Eads James B., The Riverside Biographical Series (First ed.) (Boston, Houghton, Mifflin and Company) 1-120 (2013).

12. David McCullough, The Great Bridge (1982).

13. Montgomery Schuyler, New history of architecture, The New York Times. Retrieved January 10, (2018).

14. William H. Jordy and Ralph Coe, American Architecture and Other Writings, The writings of Montgomery Schuyler (Harvard University Press, Belknap Press, Cambridge, Mass., 1961).

15. C.M. Woodward, A History of the St. Louis Bridge (St. Louis, G. I. Jones, 2005). 